\title{
Neognoza Jakuba Böhmego A III CZĘŚĆ DZIADÓW ADAMA MICKIEWICZA Wola, UPADEK CZŁoWIEKA I NAŚLAdOWANIE Chrystusa
}

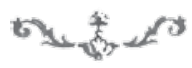

MONOLOG ZAGADKOWEGO DUCHA A NEOGNOZA JAKUBA BÖHMEGO

W tradycji badań kwestią sporną pozostaje status zagadkowego Ducha, którego monolog kończy Prolog III części Dziadów ${ }^{1}$ :

$1 \quad$ Juliusz Kleiner dowodził, że, zgodnie z wypowiedzią Ducha, człowiek posiada moc oddziaływania na historię. W Prologu, zdaniem badacza, został przedstawiony problem psychiczno-moralny Konrada, jego pokusa posiadania władzy nad dziejami, „buntowniczy rozpęd Improwizacji”, a zatem Ducha można uznać za projekcję osobowości Więźnia (J. Kleiner, Mickiewicz, t. 2: Dzieje Konrada, cz. 1, Lublin 1997, s. 314). Według Stanisława Pigonia, Prolog kończy się monologiem dobrego ducha na temat potęgi woli magicznej, poprzez którą jednostka może oddziaływać na siły przyrodzone i nadprzyrodzone (S. Pigoń, Objaśnienia, w: A. Mickiewicz, Utwory dramatyczne, oprac. S. Pigoń, Warszawa 1955, s. 497). Ponadto Pigoń w studium z lat dwudziestych XX wieku o części III Dziadów wskazywał, że wyobrażenie duchów dobrych i złych Mickiewicz mógł zaczerpnąć z pism Emanuela Swedenborga (S. Pigoń, Przypuszczalny ślad Swedenborga w III części „Dziadów”, w: tegoż, Z epoki Mickiewicza. Studia i szkice, Lwów 1922, s. 141-161). Duch w Prologu, jak dowodził Wacław Borowy, objawił prawdę o magicznej sile, którą w człowieku uaktywnia szatan bądź Duch Święty (W. Borowy, „Dziady” a magnetyzm i teozofia, w: tegoż, Kamienne rękawiczki i inne studia i szkice literackie, Warszawa 1932, s. 124). Tajemniczy Duch, według badacza, jest stworzeniem nieokreślonym, przemawiającym językiem iluminatów, teozofów i poezji, duchem ziemi (W. Borowy, O poezji Mickiewicza, t. 2, Lublin 1958, s. 89-9o. Badacz wskazał idee Johanna Baptisty van Helmonta jako źródło inspiracji dla takiego wyobrażenia mocy człowieka). Czesław Latawiec stwierdził, że wyobrażenie mocy oddziaływania przez człowieka na historię w III części Dziadów Mickiewicz zaczerpnął z pism van Helmonta oraz Louisa-Claude’a de Saint-Martina. Ducha, którego monolog kończy Prolog, należy uznać za istotę stojącą poza dobrem i złem, 
Człowieku! gdybyś wiedział, jaka twoja władza!

Kiedy myśl w twojej głowie, jako iskra w chmurze,

Zabłyśnie niewidzialna, obłoki zgromadza,

I tworzy deszcz rodzajny lub gromy i burze;

Gdybyś wiedział, że ledwie jednę myśl rozniecisz,

Już czekają w milczeniu, jak gromu żywioły,

Tak czekają twej myśli - szatan i anioły:

Czy ty w piekło uderzysz, czy w niebo zaświecisz;

A ty jak obłok górny, ale błędny, pałasz

I sam nie wiesz, gdzie lecisz, sam nie wiesz, co zdziałasz.

Ludzie! każdy z was mógłby, samotny, więziony,

Myślą i wiarą zwalać i podźwigać trony.

$$
(131)^{2}
$$

Zdaniem Wiktora Weintrauba, Duch wypowiada w dramacie myśl spirytualistyczną i heterodoksyjną, toteż nie może on być ani aniołem, ani także szatanem, a jedynie rewelatorem uniwersalnej prawdy o mocy człowieka ${ }^{3}$. Uczony wskazywał, że w widzeniu Księdza Piotra została przedstawiona wizja odkupiciela mającego moc wyższą niż Chrystusowa, a z taką przepowiednią ewolucji ludzkości Mickiewicz mógł zapoznać się podczas lektury pism Saint-Martina. Ze stanowiskiem badawczym Weintrauba polemizował Jacek Brzozowski, dowodząc, że Duch w Prologu odwołał się do Konradowego zniewolenia duchowego, marności myśli i kompleksu władzy, a zatem zapewne jest on szatanem ${ }^{4}$. Badacz określił Więźnia mianem człowieka zniewolonego. Zdaniem Haliny Krukowskiej, Duch w Prologu eksponuje rolę wewnętrznej wolności człowieka, woli oraz jej mocy, a tym samym zapowiada wymiar tragizmu w III części Dziadów ${ }^{5}$. Natomiast Magdalena Dalman uznała zagad-

istniejącą w sferze, w której człowiek czyni dobro lub zło (Cz. Latawiec, „Dziady” Adama Mickiewicza. Nowe oświetlenie problemów, Poznań 1929, s. 26-27). Z kolei Henryk Życzyński dowodził, że wypowiedź kończąca Prolog koresponduje z poglądami Paracelsusa na temat woli ludzkiej, spopularyzowanymi przez Johanna Wolfganga Goethego, zaś zagadkowy Duch to duch samego Konrada, który uświadamia sobie własną moc (H. Życzyński, „Dziady” drezdeńskie Mickiewicza. W setną rocznicę, Lublin 1932, s. 43-44).

2 Wszystkie cytaty z III części Dziadów pochodzą z wydania: A. Mickiewicz, Dziady. Część III, w: tegoż, Dzieła. Wydanie Rocznicowe, t. 3: Dramaty, oprac. Z. Stefanowska, Warszawa 1995. Po cytacie w nawiasie podaję numer strony.

3 W. Weintraub, Zagadkowy Duch w Prologu „Dziadów” części III, „,Roczniki Humanistyczne" 1976, z. 1, s. 219-223.

4 J. Brzozowski, O Prologu „Dziadów” drezdeńskich i jego zagadkowym Duchu, w: tegoż, Odczytanie znaczeń. Studia o poezji Mickiewicza, Łódź 1997, s. 121-184.

5 H. Krukowska, „O nocy cicha skąd przychodzisz?” Adama Mickiewicza „Dziady” część III, w: tejże, Noc romantyczna. Mickiewicz, Malczewski, Goszczyński. Interpretacje, Białystok 1985, s. 192-913. 
kowego Ducha za istotę złą, która dążyła do powstrzymania zainicjowanej w Prologu przemiany bohatera poprzez wskazanie mu siły myśli i możliwości walki z Bogiem ${ }^{6}$. Mickiewiczolodzy (oprócz Weintrauba) wypowiedź Ducha w Prologu łączyli z upadkiem Konrada i nie interpretowali jej w kontekście całego dramatu.

Duch twierdził, że człowiek ma możliwość ukierunkowania woli ku dobru lub ku złu. Zagadkowy bohater z Prologu nie wskazywał, czy myśl ludzka rodzi się za sprawą Boga bądź szatana, a jedynie, że powstaje w umyśle i ukonstytuowana staje się przedmiotem zabiegów boskich oraz szatańskich. Jednocześnie Duch diagnozuje, iż człowiek (niedookreślony adresat wypowiedzi, uniwersalna jednostka, ludzie w momencie historycznym powstania dramatu bądź sam Konrad) nie jest świadomy metafizycznego znaczenia woli. Poprzez myśl ludzkość uczestniczy w walce dobra ze złem, partycypuje w działaniach Boga lub szatana, decyduje o losach historii. Więzień w Prologu wątpił, aby jego myśl mogła zamanifestować się w świecie, natomiast wolności nie pojmował jako sposobu ukierunkowania jej ku dobru i złu oraz uczestniczenia poprzez nią w dziejach absolutu. Dla bohatera wolność oznaczała możliwość pełnej autoekspresji podmiotu, niemożliwej na wygnaniu i bez kontaktu ze wspólnotą narodową. Większość mickiewiczologów wskazane w Prologu dysponowanie przez człowieka władzą nad historią łączyło z żądaniem przez Konrada rządu dusz, chociaż Duch nie wskazał konkretnego sposobu, w jaki jednostka poprzez wolę może decydować o losach historii. W scenie $V$ zostało przedstawione wyłonienie się odkupiciela $\mathrm{z}$ dziejów prześladowanej Polski i upadku powstania listopadowego, wykrystalizowanie się jednostki lub zbiorowości posiadającej moc skutecznego działania w historii i stanowiącej kwintesencję boskości.

Zarysowana przez Ducha wizja woli istniejącej przed jakimkolwiek bytem, możliwości jej ukierunkowania ku dobru bądź złu oraz wpływania poprzez nią na dzieje absolutu koresponduje $\mathrm{z}$ neognostyckimi koncepcjami Jakuba Böhmego ${ }^{7}$. Mistyk ze Zgorzelca rozwinął i zradykalizował poglądy na temat

6 M. Dalman, Bóg i człowiek w świecie III części „Dziadów” Adama Mickiewicza, Gdańsk 2008, s. 69.

7 Zofia Stefanowska zauważyła, że choć nie wiadomo, kiedy Mickiewicz zapoznał się z neognostycznymi wykładniami autora Aurory, to kosmogoniczne motywy zawarte w Improwizacji wskazują na zetknięcie się poety z pismami teozofa już w latach dwudziestych. Mistyk ze Zgorzelca rozwinął i zradykalizował poglądy na temat woli anonimowego autora Teologii niemieckiej, nazywanego Frankfurtczykiem (Z. Stefanowska, Historia i profecja. Studium o „Ksieggach narodu i pielgrzymstwa polskiego” Adama Mickiewicza, Warszawa 1962, s. 248). Najważniejsze, warte odnotowania prace na temat związków twórczości Mickiewicza ze spekulacjami neognostyczymi Böhmego to: 
woli anonimowego autora Teologii niemieckiej, nazywanego Frankfurtczy$\mathrm{kiem}^{8}$. Ten mnich w piętnastowiecznym traktacie utożsamił wolę $\mathrm{z}$ istnieniem (Wesen). Frankfurtczyk, za Mistrzem Eckhartem, ujmował strukturę Wesen dialektycznie i rozróżniał jej dwa bieguny: pierwszy to Bóg potencjalny, a zarazem niezaktualizowany, istnienie samo w sobie, drugi zaś - Bóg aktualizujący się w stworzeniu'. Stwórca jako potencja aktualizująca się posiada dwa momenty: Boga ze stworzeniami bezrozumnymi (boskość aktualizująca się w sposób niedoskonały) oraz Boga-człowieka, w którym potencja urzeczywistnia się w sposób rozumny i wolny poprzez jednoczenie się w pełni z Bogiem jako istnieniem samym w sobie. Zdaniem badaczy, w Teologii niemieckiej można odnaleźć niewyrażoną expressis verbis tezę o konieczności powstania świa-

R.M. Blüth, „Chrześcijański Prometeusz”. Wpływ Böhmego na koncepcję III części „Dziadów”, w: tegoż, Pisma literackie, oprac. P. Nowaczyński, Kraków 1987; M. Burta, Adam Mickiewicz i Jakub Boehme, w: Adam Mickiewicz i kultura światowa. Materiały Konferencji Międzynarodowej Grodno-Nowogródek, 11-17 maja 1997, pod red. J. Bachórza, t. 2, Gdańsk 1998; taż, Reszta prawd. „Zdania i uwagi” Adama Mickiewicza, Warszawa 2005; M. Masłowski, „Zdania i uwagi” Adama Mickiewicza. Mądrość i samotność, „Pamiętnik Literacki” 1998, z. 4; L. Siemieński, Religijność i mistyka w życiu i poezji Adama Mickiewicza, Kraków 1871; H. Szucki, Mickiewicz a Böhme. (Przyczynki do mistyki polskiej), „Pamiętnik Literacki” 1929; S. Pigoń, Autograf „Zdań i uwag", Wilno 1929; J. Prokopiuk, Adam Mickiewicz o Böhmem, w: Wpływ myśli hermetycznej Jacoba Boehmego na życie i twórczość Adama Mickiewicza oraz jej współczesna recepcja, pod red. L. Górnickiego, Wieluń 2011. Wywody na temat böhmizmu opieram na następujących pracach: J. Böhme, Aurora, czyli Jutrzenka o poranku, przeł. A. Pańta, Zgorzelec 1998; tenże, Ponowne narodziny, przeł. J. Kałążny, A. Pańta, koment. A. Mickiewicz, Poznań 1993; tenże, Mysterium ziemskie i niebieskie, przeł. J. Jankowski, Wieluń 2008; tenże, Teozoficzne okólniki, przeł. A. Pańta, Zgorzelec 2005; tenże, Żyjacc w prostocie Chrystusa. Antologia, Wieluń 2008; J. Garewicz, Wprowadzenie w metafizykę Jakuba Böhmego, „Archiwum Historii Filozofii i Myśli Społecznej” 1987; J. Kosian, Mistyka Śląska. Mistrzowie duchowości śląskiej. Jakub Böhme, Anioł Ślązak i Daniel Czepko, Wrocław 2001; B. Markiewicz, B. Szymańska, Od mistycyzmu do symbolizmu (Jakub Boehme i Emanuel Swedenborg), Wrocław 1985; J. Piórczyński, Absolut, człowiek, świat. Studium myśli Jakuba Böhmego i jej źródła, Warszawa 1991; G. Wehr, Jakob Böhme, przeł. J. Prokopiuk, Wrocław 1999.

8 J. Piórczyński, dz. cyt., s. 78-80; P. Augustyniak, Istnienie jest Bogiem, ja jest grzechem. Theologia deutsch i początki niemieckiej filozofii, Warszawa 2013, s. 19-20, 248-249; G. Wehr, dz. cyt., s. 156. Böhme w XVII wieku stworzył zbiór ćwiczeń i medytacji pod tytułem Der Weg zu Christo. W Polsce wydano wybór fragmentów z tego zbioru zatytułowany Żyjąc w prostocie Chrystusa. Poglądy Böhmego na temat naśladowania Chrystusa przejął i rozwinął Saint-Martin (G. Wehr, dz. cyt., s. 149).

9 P. Augustyniak, dz. cyt., s. 50 i 193-258. Zob. Frankfurtczyk, Teologia niemiecka, przeł. P. Augustyniak, Warszawa 2013. Autor Teologii niemieckiej wyróżniał także Boga jako boskość stanowiącą bezgruntowość istnienia, z której wyłoniło się stworzenie. 
ta dla ukonstytuowania się Boga, którą należy uznać za heterodoksyjną ${ }^{10}$. Człowiek posiada wolę, w której wola boska istnieje jako potencja do zrealizowania. Jednostka poprzez naśladowanie Chrystusa wchodzi w obszar unio mystica, a tym samym we własnej woli urzeczywistnia wolę boską, a przez to odnajduje swoją immanencję w boskości. Natomiast, przypisując sobie odrębne istnienie, człowiek popełnia grzech annemen (wywyższenia się), bycia „sobnością” (Selbheit), posiadania własnej istoty (Ichheit), władania rzeczami wobec siebie odrębnymi i własną osobą, czyli „mojości” (Meinheit). O ile dla Frankfurtczyka wolność oznaczała ukierunkowanie woli ku dobru, o tyle dla Böhmego wiązała się także $\mathrm{z}$ wyborem pomiędzy partycypacją w działaniach Boga bądź szatana ${ }^{11}$. Jan Garewicz dowodził, że wola w ujęciu Böhmego stanowi ślepe, nieukierunkowane dążenie, natomiast jej wolność oznacza, że człowiek może się poprzez nią zwrócić ku dobru bądź złu. Jednostka zgodnie z wykładniami böhmistycznymi „ma wolny wybór pomiędzy drogą Lucyfera i Jezusa” ${ }^{12}$. Dla niemieckiego teozofa, podobnie jak autora Teologii niemieckiej, poprzez naśladowanie Chrystusa człowiek zwraca się ku dobru, uczestniczy w boskości (a właściwie jednoczy się z nią) oraz staje się podmiotem mistycznego doświadczenia. Zdaniem Böhmego, jednostka poprzez ukierunkowanie woli ku dobru bądź złu decyduje nie tylko o losach własnych, ale także świata, gdyż staje się elementem boskich lub antyboskich sił w odwiecznej walce pomiędzy Bogiem a szatanem. Jak zauważa Józef Piórczyński, według wykładni böhmistycznych:

Bóg jest w takiej samej sytuacji jak szatan i duch świata widzialnego. Każdy z nich musi oczekiwać na ludzkie decyzje. To, co najważniejsze w dziejach bytu, dokonuje się za sprawą człowieka. [...] z mocy ludzkiej wolności dochodzącej do skutku działanie decyduje o losie całego bytu. ${ }^{13}$

Zdaniem autora Aurory, człowiek partycypuje w siłach boskich poprzez podporządkowanie własnej woli Bogu, co sprowadza się do naśladowania Chrystusa, uobecniania w swojej egzystencji jego doświadczeń. Bogoczłowieczeństwo stanowi kontynuację zbawienia świata, rozpoczętą przez Jezusa pojmowanego jako Bóg-człowiek.

Tamże, s. 207.

Mickiewicz w rozprawie o autorze Aurory z lat pięćdziesiątych uznał wolę w böhmizmie za ,akt niezależny Ducha, przychodzącego do samowiedzy (A. Mickiewicz, Komentarz, w: J. Böhme, Ponowne narodziny, s. 174). Jego sposób pojmowania woli w pismach neognostyka jest bliski ujęciu wolnej woli w Teologii niemieckiej.

J. Garewicz, Jakuba Böhme spotkanie z Bogiem, „Znak” 1988, nr 12, s. 60.

J. Piórczyński, dz. cyt., s. 264. 
Określenie statusu ontologicznego tajemniczej postaci z Prologu wymaga rekonstrukcji wizji woli wpisanej w dramat Mickiewicza. W niniejszym szkicu zostanie rozpatrzony problem upadku Konrada oraz imitatio Christi najprawdopodobniej przedstawiony w widzeniu Księdza Piotra. Tym samym zostanie rozważona kwestia statusu ontologicznego zagadkowego Ducha oraz podobieństwa pomiędzy heterodoksyjnymi spekulacjami neognostycznymi Böhmego a wizją religijną zawartą w III części Dziadów.

\section{KONRADOWE UKIERUNKOWANIE WOLI KU ZŁU \\ A NEOGNOSTYCZNE KONCEPCJE JAKUBA BÖHMEGO}

Renesansowi myśliciele rozwinęli pitagorejsko-platońską wizję machina mundi jako tętniącego życiem organizmu ${ }^{14}$. W dobie odrodzenia filozofowie dowodzili istnienia analogii pomiędzy makrokosmosem rozwijającym się wokół boskiego środka a mikrokosmosem ludzkim, duszą rozrastającą się z promieniejącego punktu i kreującą swoją sferę oddziaływania, zawierającą w sobie wszystkie potencjalności stworzenia oraz różnorodność form ${ }^{15}$. Kosmologia Böhmego stanowiła kontynuację renesansowych spekulacji na temat wszechświata, natury i Boga. Według Piórczyńskiego romantyczne wizje makro- i mikrokosmosu w sposób mniej lub bardziej bezpośredni były zapożyczone z nauk myśliciela ze Zgorzelca i ich zwolenników (zwłaszcza Louisa-Claude’a de SaintMartina i Franza von Baadera) ${ }^{16}$. Georges Poulet dowodził, że europejski romantyzm charakteryzuje się przekonaniem o istnieniu centralitas myśli, czyli pojmowaniem człowieka jako centrum (dzięki aktywności myśli ludzkiej) oraz okręgu (dzięki nieskończonej zawartości owej myśli) ${ }^{17}$. Zdaniem badacza, romantycy (za Böhmem i kontynuatorami jego myśli) poszukiwali w umyśle nie tylko boskiej genezy stworzenia, ale także geniuszu oraz samego Boga.

W Improwizacji Konrad dokonuje aktu wykreowania i przekroczenia natury, który przypomina Böhmowską wizję działań Boga. W scenie I Więzień jest ogarnięty pragnieniem zemsty oraz gniewu, a zatem stanów charaktery-

14 S. Świeżawski, Dzieje filozofii europejskiej XV wieku, t. 5: Wszechświat, Warszawa 1980, s. $383-385$.

15 G. Poulet, Pisarze i przestrzeń, w: tegoż, Metamorfozy czasu. Szkice krytyczne, przeł. W. Błońska, D. Eska, A. Siemek, A. Stepnowski, P. Taranczewski, Warszawa 1977, s. 366-367.

16 J. Piórczyński, dz. cyt., s. 29-30. Autor L’Homme de désir stwierdził: „Podziwiałem, jak źródło wszechrzeczy ożywia wszelką istotę ludzką i nasyca ją ogniem nieugaszonym, początkiem wszelkiego ruchu. Każda istota tworzy jakby centrum, w którym odbijają się wszystkie punkty jej własnej sfery” (cyt. za: G. Poulet, dz. cyt., s. 436).

17 Tamże, s. 439-446. 
stycznych dla woli w pierwszym principium w ujęciu Böhmego. Myśliciel ze Zgorzelca twierdził, że Stwórca powołał do istnienia naturę, aby w niej ukonstytuowała się Jego boskość, natomiast wyobraźnię pojmował jako domenę nieskończoności. Poprzez wyobraźnię człowiek może uczestniczyć w boskim bądź szatańskim fiat. W scenie II bohater tworzy pieśń podobną do wyobrażeń harmonia mundi, z którą identyfikuje się, a zarazem twierdzi, że ją przekracza. Zdaniem Włodzimierza Szturca, Konrad pragnie wejść w harmonię kosmosu, aby odnaleźć tam duchowe principium, wyższe od doczesnego ży$\mathrm{cia}^{18}$. Bohatera, według badacza, transcendentuje historyczno-egzystencjalna sytuacja. Bóg, zgodnie z wykładnią autora Aurory, jest transcendentalny względem natury, a jednocześnie manifestujący się w niej. Konrad, jak dowodził Bolesław Oleksowicz, podkreślał, że źródła jego natchnienia istnieją w nim samym, nie zaś w Stwórcy, a do tworzenia potrzebne są jedynie moce własnego ducha ${ }^{19}$. Zdaniem bohatera, jego akt twórczy jest naśladowaniem aktu kreacyjnego Boga. Trzykrotnie przedstawia on naturę jako oddzieloną od Stwórcy, upatrując w niej jednocześnie manifestację Jego istoty: „Ty Boże, ty naturo! dajcie posłuchanie. - / Godna to was muzyka i godne śpiewanie” (157); „Ja czuję nieśmiertelność, nieśmiertelność tworzę, / Cóż Ty większego mogłeś zrobić - Boże?” (158); „Odezwij się - bo strzelę przeciw Twej naturze” (165).

Lukrecjusz, myśliciel wymieniony w scenie III jako reprezentant szatana, w dziele De rerum natura dowodził, że człowiek może odnieść triumf nad naturą i równać się z bogami, którym cześć oddaje jedynie z powodu swoich lęków i pesymistycznej wizji własnej osoby ${ }^{20}$. Co więcej, nawoływał do odrzucenia teologii na rzecz poznawania rzeczywistości poprzez prawdy serca. Natomiast zdaniem Böhmego, w pierwszym principium wola pochodząca z Ungrund pragnie natury, gdyż tylko w niej może zamanifestować swoją istotę. Z kolei boskość do ukonstytuowania siebie i przezwyciężenia zła tkwiącego w Ungrund potrzebuje natury jako swojego dynamicznego bytu. W Prologu Więzień wyraził zarazem pragnienie, jak i niemożność dokonania aktu twórczego. W Improwizacji wyłonienie się ,pieśni” z myśli bohatera przypomina stworzenie natury według Böhmego, gdyż wykreowanie dzieła poprzedzone jest przeżyciem wściekłości i pragnieniem poznania, a zatem doświadczeniem

W. Szturc, Idea „wielkiej całości”. Od oświecenia ku romantyzmowi, w: tegoż, O obrotach sfer romantycznych. Studia o ideach i wyobraźni, Bydgoszcz 1997, s. 20-21.

19 B. Oleksowicz, ,Kładę me dłonie na [...] szklanych harmoniki kręgach”, w: tegoż, „Dziady”, historia, romantyzm. Studia i szkice, Gdańsk 2008, s. 176.

20 G. Reale, Historia filozofii starożytnej, t. 3: Systemy epoki hellenistycznej, przeł. E.I. Zieliński, Lublin 1996, s. 294-297. Zob. Tytus Lukrecjusz Karus, O rzeczywistości, przeł. A. Krokiewicz, Wrocław 1958. 
jakości woli charakterystycznych dla pierwszego princpicium w ujęciu neognostyka ze Zgorzelca. Konrad tworzy „pieśń”, którą określa jako manifestację posiadanej przez siebie mocy oraz istoty, a równocześnie utożsamia ją z naturą (zarazem własną i boską), oraz pragnie przekroczyć swoje dzieło. Mickiewicz w Improwizacji przedstawił znane w kulturze europejskiej od czasów renesansu i rozwinięte przez Böhmego oraz kontynuatorów jego myśli wyobrażenie boskiego elementu istniejącego w człowieku, z którego wyłania się mikrokosmos, stanowiący bosko-ludzką sferę oddziaływania, pełną różnorodnych form i potencjalności. W postępowaniu Więźnia można zauważyć elementy naśladowania aktu stwarzania świata. Konradowa imitatio Dei nie prowadzi jednak do zjednoczenia ze Stwórcą, wręcz przeciwnie, chociaż przyczynia się do doświadczenia doskonałości oraz mistrzostwa, to jednocześnie staje się dla bohatera podstawą separacji własnego istnienia od Boga i próby jego detronizacji. Agnieszka Ziołowicz wskazywała, że Mickiewiczowski bohater poprzez umieszczenie swojej woli w centrum kosmosu, odtworzył akt boskiej autokreacji, co doprowadziło go do grzechu pychy i autodestrukcji ${ }^{21}$. Więzień, jak słusznie zauważa Ryszard Przybylski, w swoim monologu zupełnie pomija znaczenie wcielenia Chrystusa dla zbawienia człowieka i świata ${ }^{22}$. Poeta w scenie V przedstawił wyłanianie się z historii odkupiciela, którego doświadczenia przypominają Chrystusowe. Szturc dowodził, że w widzeniu Księdza Piotra została zobrazowana wizja porządku kosmicznego, w którego centrum znajduje się Syn Boży, co stanowi odpowiedź na pytania Konrada o przyczynę istnienia zła ${ }^{23}$. W Improwizacji Mickiewicz zarysował, jak nowożytna imitatio Dei - nieuwzględniająca tajemnicy wcielenia oraz oddzielona od imitatio Christi - może przerodzić się w imitatio diaboli ${ }^{24}$.

W Improwizacji element boskości w człowieku stanowi siłę stwarzającą świat. Pytanie o osobowy charakter Boga nie zostaje podjęte przez Konrada,

21 A. Ziołowicz, Misterium jako fragment całości. O III części „Dziadów” Adama Mickiewicza, w: tejże, „Misteria polskie”. Z problemów misteryjności $w$ dramacie romantycznym i młodopolskim, Kraków 1996, s. 42.

22 R. Przybylski, Wzlot i upadek Bohatera Polaków, w: tegoż, Słowo i milczenie Bohatera Polaków. Studium o „Dziadach”, Warszawa 1993, s. 101-174.

23 W. Szturc, Kosmos Adama Mickiewicza, w: tegoż, O obrotach sfer romantycznych..., s. $98-100$.

24 Joanna Jagodzińska w studium na temat romantycznego dramatu wskazywała elementy naśladowania Boga w postępowaniu Konrada, które doprowadziły go do upadku i wejścia w rolę szatana (J. Jagodzińska, ,Dziadów” cz. III Adama Mickiewicza jako „dramat eucharystyczny”, w: tejże, Misterium romantyczne. Liturgiczno-rytualne wymiary świata przedstawionego w III części ,Dziadów” Adama Mickiewicza, „Nie-Boskiej komedii” Zygmunta Krasińskiego i „Księdzu Marku” Juliusza Słowackiego, Toruń 2006, s. 116-120). 
natomiast w dalszych partiach sceny II bohater zarzuca Stwórcy, że jest jedynie mądrością. Zdaniem Henryka Życzyńskiego, przypisywanie Bogu atrybutu mądrości jest charakterystyczne dla teistów, według których istnieje raz na zawsze ustalony porządek rozwoju świata ${ }^{25}$. Voltaire, głosiciel teizmu, uważał, że Stwórca nie ma charakteru osobowego. Szatan podczas rozmowy z Księdzem Piotrem stwierdził, że Voltaire jest jednym z jego reprezentantów. W scenie V dramatu Mickiewicza dusza Księdza Piotra została wzięta do trzeciego nieba, przez co najprawdopodobniej poeta zarysował wizję osobowego Boga. Mickiewiczowska krytyka nurtów nowożytnego myślenia (między innymi heglizmu) dowodzących, że Stwórca nie ma osobowego charakteru, człowiek zaś w akcie tworzenia uruchamia siły boskości i może osiągnąć doskonałość, koresponduje z polemiką Friedricha Jacobiego z systemami transcendentalnymi i idealistycznymi, którego myśl, zdaniem Piórczyńskiego, zawiera wiele locis communis z böhmizmem ${ }^{26}$. Według Jacobiego, ,ja” w ujęciu Johanna Fichtego stanowi abstrakcję ,ja" indywidualnego, które zawiera w sobie boską naturę stworzyciela świata ${ }^{27}$. Toteż postulaty filozoficzne Fichtego doprowadzają do dylematu: ,albo Bóg istnieje poza mną jako żywa istota istniejąca dla siebie, albo Ja jestem Bogiem. Trzeciej drogi nie ma"28. Transcendentaliści, zdaniem Jacobiego, wybrali pierwszą odpowiedź i stali się przez to nihilistami, gdyż wszystko, co znajduje się poza rozumem, uznali za nicość. „Ja” absolutne, według niemieckiego myśliciela, niszczy wszystko, co jest obiektywne, a tym samym konstytuuje siebie jako absolutne źródło sensu. Konrad uznaje istnienie Boga transcendentalnego względem stworzenia, który milczy w obliczu zła oraz sprawiedliwości, aczkolwiek - jako istota wszechwładna - może ochronić niewinnych. Toteż bohater uznaje Stwórcę za obiektywne źródło zła, siłę rządzącą światem w sposób mechaniczny, sam zaś identyfikuje się z atrybutami tradycyjnie przypisywanymi Bogu. Odpowiedź Mickiewiczowskiego bohatera na dylemat transcendentalistów brzmiałaby następująco: Bóg istnieje jako istota istniejąca dla siebie i niedbająca o świat, natomiast ,ja” posiada wszystkie atrybuty Stwórcy, wszystkie siły boskie zorientowane na miłość do rodzaju ludzkiego tkwią w podmiocie.

H. Życzyński, dz. cyt., s. 55.

J. Piórczyński, Byt ludzki, w: tegoż, Pierwszy egzystencjalista. Filozofia absolutnej skończoności Fryderyka Jacobiego, Wrocław 2006, s. 100-121.

P. Dehnel, Nihilizm jako konsekwencja idealizmu. F.H. Jacobiego krytyka filozofii transcendentalnej, w: tegoż, Antynomie rozumu. Z dziejów filozofii niemieckiej XVII i XIX wieku, Wrocław 1998, s. 114.

Cyt. za: tamże, s. 114. 
Mistyka Mistrza Eckharta i Böhmego wpisuje się w orientację mistyczną i egzystencjalną w niemieckiej filozofii doby romantyzmu ${ }^{29}$. Konrad, w którym można odnaleźć znamiona ,ja” indywidualnego i absolutnego, konstruuje swoją tożsamość w opozycji do ludzkości bezbronnej i bezsilnej wobec dziejącego się zła. Korzeni bytu (własnego i stworzenia) upatruje w przypadkowości iskry i chwili ${ }^{30}$, zaś swoje doświadczania zła uważa za wyjątkowe oraz niepowtarzalne, wynoszące go ponad innych ludzi. Bohater nie potrafi znieść cierpienia oraz niesprawiedliwości (na przykład poprzez ufność wobec wszechmocy boskiej, jak w wypadku Księdza Piotra), bunt zaś uznaje za najwyższy stopień odczuwania zła. Doświadczenie opresji politycznej nie buduje więzi pomiędzy nim a współwięźniami, ale izoluje go od wspólnoty, powoduje niedopuszczanie do siebie naturalnych form wsparcia międzyludzkiego, blokuje odsłanianie własnych emocji i paraliżuje komunikację z bytem konkretnym, jakim jest drugi człowiek. Konrad, umieszczając swoje twórcze „ja” w ramach złudnej twórczej konstrukcji, odwraca się od Boga jako dawcy istnienia oraz kwestionuje boską moc oraz dobroć względem ludzi, natomiast siebie samego uznaje za źródło siły zbawczej, jednocześnie nie zauważając, że jego pragnienia stają się autorytarne. Mickiewicz w III części Dziadów przedstawił problem teodycei w kontekście utraty umiejętności pozostawania w bliskich i kojących relacjach z innymi ludźmi oraz kompensacji braku ludzkiego zakorzenienia w bycie. Konrad dąży do rozmowy z Bogiem, pojmowanym przez niego jako byt abstrakcyjny, twór spekulacji filozoficznych, który konsekwentnie milczy. Według mistyków niemieckich (w tym także Böhmego) człowiek, aby dostąpić zbawienia, powinien dążyć do zniesienia własnej partykularności przez zjednoczenie z absolutem, podporządkować własną wolę Stwórcy, jak czynią to w dramacie Ksiądz Piotr i Ewa. Konrad konstytuowanie siebie jako bytu rozpoczyna od aktu stwarzania $\mathrm{z}$ woli tkwiącej w nim, a zarazem w stworzeniu. Z owej woli bohater wyprowadza podmiotowość własnego istnienia - pieśń-naturę, z którą się identyfikuje. W podobny sposób ruch woli z nicości opisywali Böhme i Fichte, z tym, że pierwszy z wymienionych myślicieli uważał, iż wolność (jako wszechmocna wola) rozpoznaje się w przedmiotowości, nie zaś w podmiotowości ${ }^{31}$. Dla Böhmego rozpoznawanie się woli ludzkiej w podmiotowości bądź w atrybutach boskich stanowi sedno grzechu Lucyfera i Adama, skutkującego zwróceniem się przeciwko Bogu. Zło, według myśli-

29 L. Kołakowski, Filozoficzna rola reformacji, „Archiwum Historii Filozofii i Myśli Społecznej” 1969, s. 174-175.

30 Konrad stwierdza w Improwizacji: „Chwila i iskra, gdy się przedłuża, rozpala - / Stwarza i zwala" (163).

31 J. Piórczyński, Absolut, człowiek, świat..., s. 136-139. 
ciela ze Zgorzelca, tkwi we własnej woli bytu skończonego, który ustanawia swój obszar posiadania i istnienia. Konrad, dążąc do utwierdzenia siebie samego na podstawie własnej partykularności wymierzonej przeciwko Bogu, ustanowił swój obszar istnienia i posiadania we własnym dziele oraz cierpiącym narodzie. Można przypuszczać, że, podobnie jak w Böhmowskim ujęciu upadku Lucyfera i Adama, ukierunkowanie przez Konrada woli przeciwko Bogu, a przez to partycypacja w szatańskich działaniach, stanowi matrycę grzechu bohatera. Najprawdopodobniej w planie egzystencjalnym to właśnie odwrócenie woli od Stwórcy prowadzi do partykularyzacji własnego istnienia, co skutkuje odczuwaniem przez Konrada samotności, nieprzekazywalności własnej subiektywności, braku więzi z ludźmi, a ostatecznie niewiarą w istnienie jakiekolwiek dobra.

Więzień w Prologu wyraża potrzebę urzeczywistnienia siebie i zarazem wątpi, aby to było możliwe („I myśl legnie zamknięta w duszy mojej cieniu”; 131). W pierwszych scenach części III Dziadów bohater podejmuje próby autoekspresji poprzez dążenie do profetycznego widzenia, kreowanie pieśni-natury oraz poszukiwanie stwórczo-zbawczej aktywności. Według Böhmego dusza człowieka, która, jak zauważa Więzień w Prologu, powinna stać się przedmiotem badań ludzkich, jest obszarem realizowania się absolutu, natomiast jednostka osiąga pełnię rozwoju oraz urzeczywistnienia, gdy jednoczy się z Bogiem. Konrad w Małej i Wielkiej Improwizacji określa swoje działania i siebie samego jako odseparowanie od Stwórcy, którego pojmuje statycznie (jako oddzielonego od natury i historii, na które może oddziaływać). Dla neognotyka ze Zgorzelca oraz autora Teologii niemieckiej matrycę grzechu Lucyfera i Adama stanowi oddzielenie się od Boga, ujęcie własnego bytu jako zewnętrznego względem niego. Natomiast poprzez ponowne zjednoczenie się ze Stwórcą, dusza staje się obszarem urzeczywistniania się boskości oraz formowania się bogoczłowieczeństwa na wzór Chrystusa, co jest warunkiem zbawienia własnej osoby i uczestnictwa w ukonstytuowaniu się bytu boskiego w historii. W widzeniu Księdza Piotra zostało opisane prześladowanie narodu polskiego oraz wyłanianie się odkupiciela. Toteż w świecie przedstawionym w III części Dziadów oddzielenie przez człowieka własnego istnienia od Boga (rozumianego jako aktualizująca się potencjalność), własnej woli od boskiej można uznać za podstawę grzechu oraz przyczynek do partycypacji w działaniach szatana.

Jacek Brzozowski w Duchu występującym w Prologu upatruje szatana, który opętał Konrada i pchnął go w stronę grzechu pychy ${ }^{32}$. Badacz w swoim

J. Brzozowski, dz. cyt., s. 140, 161. 
wywodzie pomija obronę imienia Maryi przez Więźnia, czyn świadczący o braku jego jednoznacznie antyreligijnej postawy w scenie I. W Prologu Duch z lewej strony, wabiąc bohatera uciechami życia, wspominał o „kometach”, w których kierunku zwrócenie się jest równoznaczne z wejściem w sferę szatańską. W scenie II Głos z lewej strony określił Więźnia jako spadającą kometę błędu. W Prologu w wypowiedziach Duchów z lewej i z prawej strony oraz Aniołów pojawił się problem woli ludzkiej i jej ukierunkowania. Rację należy przyznać Wacławowi Borowemu, który twierdził, że Konrad, choć jest pozbawiony zdolności profetycznych, to dysponuje potęgą woli ${ }^{33}$. Przede wszystkim bohater, powtórzmy, uważa, że jego wola jest jego własnością oddzieloną od woli boskiej, co, zdaniem autora Aurory, stanowi grzech. Konrad, podobnie jak Lucyfer i Adam w ujęciu Böhmego, ma wolność wyboru, czyli ukierunkowania woli ku Bogu bądź przeciwko niemu, jednak nie dysponuje mocą, aby tę wolność całkowicie zrealizować, czyli zdetronizować Stwórcę, odebrać mu władzę. Voltaire, którego szatan w scenie III uznał za swojego reprezentanta, w Essai sur les mours et l'esprit des nations dowodził, że dzieje nie toczą się podług boskiej Opatrzności, gdyż Bóg nie ingeruje w historię, nad którą władzę przejął człowiek ${ }^{34}$. Ludzie, zdaniem francuskiego filozofa, powinni poprzez własną wolę i rozum dążyć do ulepszenia międzyludzkich relacji oraz eliminować zło. W upadku Więźnia można zauważyć wiele podobieństw do opisów ukierunkowania woli ku złu, zawartych w Teologii niemieckiej i pismach neognostyka ze Zgorzelca. Bohater wskutek doświadczenia zła i milczenia Boga, pragnie poznać przyszłość, a zatem przywłaszczyć wiedzę boską. Oddziela własne istnienie od Stwórcy, ustanawia własną tożsamość (grzech „,sobności”), staje się podmiotem własnych aktów twórczych, pragnie posiąść władzę nad ludźmi (grzech „mojości”), wywyższa się ponad naturę i Boga (grzech annemen), ostatecznie pragnie przejąć władzę nad historią, a zatem zdetronizować Stwórcę. Konrad, z punktu widzenia Böhmego, grzeszy nie dlatego że został opętany przez szatana, ale z powodu ukierunkowania woli przeciwko Bogu, przez co powtarza grzech Lucyfera i Adama, oraz zaczyna partycypować w siłach szatańskich, czego przejawem jest namawianie Rollisona do samobójstwa. Jednak o ile w kreacji Konrada, jak można przypuszczać, Mickiewicz przedstawił elementy upadku nowożytnej jednostki w systemie władzy absolutnej, o tyle portret człowieka zniewolonego można odnaleźć w postaci Senatora, odpowiedzialnego za śmierć Rollisona i cierpienie jego matki.

33 W. Borowy, „Dziady” a magnetyzm i teozofia, s. 123.

34 K. Löwith, Wolter, w: tegoż, Historia powszechna i dzieje zbawienia. Teologiczne przesłanki filozofii dziejów, przeł. J. Mąrzecki, Kęty 2002, s. 100-110. 
ZBAWIENIE NARODÓW POPRZEZ NAŚLADOWANIE CHRYSTUSA

Idea naśladowania Chrystusa była propagowana w chrześcijaństwie niemalże od jego początku. Postulat imitatio Christi był niezwykle popularny w XV wieku. Propagowali ją między innymi Mistrz Eckhart, Johannes Tauler, Heinrich Suso, wspomniany już Frankfurtczyk w Teologii niemieckiej. Böhme, powtórzmy, rozwinął i zradykalizował ideę naśladowania Chrystusa ${ }^{35}$. Dla autora Aurory pokuta oraz doskonalenie jednostki sprowadza się do naśladowania Syna Bożego. Poprzez tę duchową praktykę jednostka zdobywa mądrość Chrystusową (chrystozofię) oraz przyczynia się do przywrócenia kondycji ludzkiej sprzed upadku Adama. Zdaniem Böhmego, dzięki imitatio Christi człowiek uwewnętrznia we własnej egzystencji doświadczenie Chrystusa, staje się narzędziem działania Boga w historii, partycypuje po stronie dobra w odwiecznej walce ze złem, nabiera bogoczłowieczeństwa, choć pełna transformacja ludzkości i dziejów będzie możliwa, według autora Aurory, dopiero wraz z Sądem Ostatecznym.

Według Szturca, widzenia Ewy i Księdza Piotra stanowią epifanię rzeczywistości transcendentalnej, objawienie porządku wszechświata, w którego środku stoi Chrystus, oraz odpowiadają na pytanie Konrada o teodyceę ${ }^{36}$. Michał Masłowski dowodził, że w scenie V Mickiewicz przedstawił heroiczny model imitatio Christi ${ }^{37}$. W tradycji badań nad Dziadami drezdeńskimi

Böhme twierdził: „W żadnym wypadku nie powinniśmy mówić, co my chcielibyśmy wiedzieć, lecz jedynie rozpocząć proces stawania się człowiekiem oraz wejść do narodzin Jezusa Chrystusa w Jego cierpieniu i śmierci oraz coraz chętniej pragnąć podążać Jego krokami i na śladow ać Go, a także stale myśleć o tym, że znajdujemy się na ścieżce pielgrzyma. [...] Mamy prawo powiedzieć jedynie: je s t e m w C h r y s t u s i e, a Chrystus stał się we mnie człowiekiem (J. Böhme, Żyjąc w prostocie Chrystusa, s. 69 i 87; podkr. - K.F.). Mickiewicz w rozprawie o Böhmem z lat pięćdziesiątych następująco opisuje kwestię naśladowania Chrystusa w boehmizmie: „Jezus Chrystus urzeczywistnił na ziemi ideał człowieka, poczęty w niebiosach, zdradzony przez Adama; podniósł go nawet do nowej potęgi, pozostawiając dzieciom Adama sposoby wyjścia z otchłani, w którą wpadły, jednakże pod warunkiem wzniesienia się wyżej niż Adam w raju, wzniesienia się aż do nieba. [...] Jezus Chrystus udzielał się uczniom swoim, ukazując im modłę i użyczając im równocześnie siły do naśladowania go" (A. Mickiewicz, Komentarz, s. 172).

36 W. Szturc, Kosmos Adama Mickiewicza, s. 98-101.

37 M. Masłowski, Wiara i historia, w: tegoż, Gest, symbol i rytuał polskiego teatru romantycznego, Warszawa 1998, s. 302-303. Co istotne, Jarosław Ławski wskazywał, że w scenie IV dramatu Mickiewicz zobrazował włączenie Konrada do wspólnoty naśladowców Chrystusa (J. Ławski, Pielgrzym i Ewa, w: tegoż, Marie romantyków. Metafizyczne wizje romantyków. Mickiewicz. Malczewski. Krasiński, Białystok 2003, s. 237-242). 
w wyobrażeniu narodu polskiego w widzeniu Księdza Piotra upatrywano upodobnienie Polaków do Chrystusa, a nawet - utożsamienie ${ }^{38}$. Bogusław Dopart wskazał na pięć możliwych sposobów rozumienia paraleli pomiędzy nowotestamentowym Jezusem a „wskrzesicielem narodu”39. Charakterystyka odkupiciela zbieżna z ewangelicznym podaniem o Chrystusie może stanowić fikcję ekspresyjną, metaforę ontologiczną, alegorię ideologiczną, figurę biblijną o wymowie wieszczby millenarystycznej lub symbol teologiczny. Badacz dowodził, że analogia pasyjno-rezurekcyjna w Widzeniu oznacza „heroiczne naśladowanie Chrystusa, męczeństwo, ofiarę, eschatologiczne rozstrzygnięcie losów narodu", nie zaś deifikację narodu czy też przedstawienie go jako narodu zbawcy $^{40}$. Ewa i Ksiądz Piotr prześladowcę narodu nazywają Herodem. Böhme uważał, że podczas narodzin Chrystusa w człowieku pojawia się Herod, który dąży do zniszczenia Syna Bożego i wystawia jednostkę na liczne próby ${ }^{41}$. Człowiek, aby oprzeć się złu, musi wytrwać w imitatio Christi, czyli ukierunkowaniu woli ku Bogu, oraz powtórzyć we własnej egzystencji doświadczenie Chrystusa. Według przekazu ewangelicznego Jezus od dziecięctwa był świadomy własnej roli w dziejach zbawienia i realizował boskie posłannictwo. Natomiast

38 Józef Kallenbach podkreślał w monografii o Mickiewiczu, że „Osnowa polityczna widzenia jest jasna i miała być brzemienna w następstwa literackie i społeczne w piśmiennictwie emigracyjnym polskim. Tą osnową jest przyrównanie Polski do Chrystusa Pana, a jego jej cierpień porozbiorowych do cierpień Zbawiciela na krzyżu” (J. Kallenbach, Adam Mickiewicz, t. 2, Lwów 1926, s. 65). Jak zauważa Alina Witkowska, ofiara Polski przedstawiona w scenie V ma podwójny sens: „została złożona za wolność i za wszystkich. Jest więc głęboko odkupicielska i można ją porównać do ofiary Chrystusa" (A. Witkowska, Mickiewicz. Słowo i czyn, Warszawa 1975, s. 149). Natomiast Wacław Kubacki twierdził, że „[...] w Widzeniu księdza Piotra Polska zostaje mesjaszem narodów” (W. Kubacki, Arcydramat Mickiewicza. Studia nad III częściq „Dziadów”, Kraków 1951, s. 152). Z kolei Stefanowska dowodziła, że w części III Dziadów Polacy zostali utożsamieni z Chrystusem: „Polska - jak Chrystus - stać się miała odkupicielem, Mesjaszem narodów. [...] Polska umiera jak Chrystus na krzyżu” (Z. Stefanowska, Posłowie, w: A. Mickiewicz, Dziady, oprac. Z. Stefanowska, Warszawa 1986, s. 125). Zob. B. Dopart, Polska - Chrystusem narodów?, w: tegoż, Poemat profetyczny. O „Dziadach" drezdeńskich Adama Mickiewicza, Kraków 2002, s. 191-194.

40 Tamże, s. 204.

41 Böhme twierdził: „Człowiek musi się modlić gorliwie i z wielką pokorą. Na pewien czas musi stać się głupcem wobec swego rozumu i rozpoznać siebie samego jako pozbawionego rozsądku - do chwili, gdy Chrystus przyjmie postać określoną przez proces stawania się nowym człowiekiem. Jednak podczas narodzin Chrystusa pojawia się jednocześnie Herod, gotowy uśmiercić dziecię i wypróbować je: zewnętrznie - w postaci prześladowań, a także wewnętrznie - wystawiając na liczne pokusy i sprawdzając, czy owa gałąź lilii okaże się wystarczająco silna, by zniszczyć królestwo diabła, które objawiło się w ciele" (J. Böhme, Żyjąc w prostocie Chrystusa, s. 94). 
ukazany w widzeniu Księdza Piotra odkupiciel jest istotą ewoluującą do bogoczłowieczeństwa - wszak, jak twierdzi bernardyn, jest „On ślepy, lecz go wiedzie anioł pacholę” (190). W Prologu Więzień także zostaje przedstawiony przez Anioła Stróża jako istota niezdolna do trwałego skierowania się ku Bogu. Można więc przypuszczać, że wypowiedź Ducha w Prologu na temat nieświadomości mocy, jaką człowiek dysponuje dzięki woli, dotyczy zarówno Konrada, jak i wyłaniającego się wskrzesiciela narodu. W scenie V została wyraźniej zarysowana paralela pomiędzy prześladowcami Chrystusa i narodu polskiego niż pomiędzy ewangelicznym przedstawieniem Syna Bożego a „wskrzesicielem narodu”. Zło, którego doświadczyli Polacy, jest powtórzeniem zła doświadczonego i przezwyciężonego przez Jezusa, a zatem staje się dopiero matrycą do wyłonienia się odkupiciela. Mickiewicz w Przedmowie do III części Dziadów wskazał, że męczeństwo, jakie dotknęło jego rodaków, przypomina jedynie cierpienia pierwszych chrześcijan i inicjuje pojawienie się nowego chrześcijańskiego odrodzenia.

Problem analogii pomiędzy Chrystusem a wskrzesicielem narodu można rozważyć także w kontekście teologicznych sporów toczonych w pierwszych wiekach naszej ery o homouzję, czyli konsubstancjalność pomiędzy Jezusem a Bogiem. Mickiewicz mógł zapoznać się z tym problem między innymi podczas lektury Zmierzchu Cesarstwa Rzymskiego Edwarda Gibbona ${ }^{42}$. Poeta w latach czterdziestych dowodził podczas wykładów w Collège de France, że należy zaniechać pytań o status ontologiczny Chrystusa na rzecz pełnienia Jego posłannictwa i stawania się bogoczłowiekiem ${ }^{43}$. Dla autora Dziadów, podobnie jak Böhmego, Jezus jako Syn Boży wyznaczył wzór postępowania wiodącego do przekształcania jednostkowego i wspólnotowego życia oraz skutecznego działania w historii. W dramacie Mickiewicza naród polski został ukazany jako predestynowany do pełnienia posłannictwa Chrystusowego wśród innych nacji ze względu na szczególne doświadczenie prześladowania. Jednak w III części Dziadów społeczeństwo polskie zostało ukazane jako zbiór jednostek o różnych postawach, w tym także zdradzieckich, a zatem szatańskich. Natomiast w kreacji Księdza Piotra, jak wskazywał Juliusz Kleiner, można dostrzec nawiązania do wzoru prawdziwego chrześcijanina zarysowanego w dziele $O$ naśladowaniu Chrystusa Tomasza à Kempis ${ }^{44}$. Warunkiem

42 Zob. List do Joachima Lelewela, Rzym, 6 lutego [183o], w: A. Mickiewicz, w: tegoż, Dzieła..., t. 15: Listy. Część druga: 1830-1841, oprac. M. Dernałowicz, E. Jaworska, M. Zielińska, Warszawa 2003, s. 20.

43 A. Mickiewicz, Wykład X, w: tegoż: Dzieła..., t. 11: Literatura słowiańska. Kurs czwarty, przeł. L. Płoszewski, oprac. J. Maślanka, Warszawa 1998, s. 128.

44 J. Kleiner, dz. cyt., s. 416. 
wyłonienia się z narodu polskiego odkupiciela jest nie tylko ukrzyżowanie w postaci prześladowań porozbiorowych, ale także przejście duchowej transformacji. Weintraub wypowiedź Ducha w Prologu na temat mocy człowieka łączył z wizją odkupiciela w scenie V. Badacz wskazywał, że ,wskrzesiciel narodu” został ukazany jako istota o mocy Chrystusowej, nowy człowiek opisywany także przez Saint-Martina ${ }^{45}$. Według zagadkowego Ducha moc działania człowieka w historii wywodzi się z jego woli, a zatem można przypuszczać, że duchowa transformacja narodu ku pełnieniu posłannictwa Syna Bożego obejmuje imitatio Christi, ale także - co zostało zaakcentowane w widzeniu Księdza Piotra - uwewnętrznienie doświadczeń Jezusa i wytrwanie do końca w posłuszeństwie wobec Stwórcy. Motta z Ewangelii do III części Dziadów zawierają wypowiedzi Chrystusa adresowane do apostołów na temat ich przyszłego prześladowania i konieczności pozostania w wierze w Syna Bożego podczas przeżywania niezasłużonych cierpień: „Ale kto wytrwa do końca, ten będzie zbawion" (Mat 10, 22).

$\mathrm{W}$ tradycji badawczej istnieje wiele hipotez interpretacyjnych na temat wizji zbawiciela o imieniu czterdzieści i cztery ${ }^{46}$. W liczbie cztery badacze (m.in. Ju-

46 Kleiner uważał, że symbolikę liczby czterdzieści i cztery Mickiewicz zaczerpnął z pism saint-martinistów rosyjskich nawiązujących do kabały. Jak zaznaczał badacz, „,Mesjasz zapowiedziany, mąż czterdzieści i cztery to nowy Adam, Adam-Mesjasz, oczekiwany i przez kabalistów, i przez wyznawców Böhmego" (J. Kleiner, dz. cyt., s. 435). Także Weintraub wskazywał na pisma Saint-Martina jako źródło, z którego Mickiewicz mógł zaczerpnąć symbol imienia wyzwoliciela przedstawionego w Widzeniu Księdza Piotra: „Dla naszych celów powinien wystarczyć ten zarys sensu, jaki się z tych pytyjskich oparów wyłania, a mianowicie, że czterdziestka jest cyfrą dzieła o wielkiej duchowej doniosłości, dzieła odkupienia, wyzwolenia i pogodzenia. Przykłady podane w tym ustępie najprawdopodobniej odnoszą się do ezoterycznych interpretacji kabalistycznego i gnostycznego pochodzenia. Słowa o Mojżeszu być może mają swe zahaczenie w zdaniu: «I był Mojżesz na górze czterdzieści dni i czterdzieści nocy» (Exod., 24, 18). [...] Imię «czterdzieści i cztery» to imię Pośrednika, który dokona «wielkiego dzieła»" (W. Weintraub, „Dziadów” część trzecia: manifest profetyzmu, w: tegoż, Poeta i prorok. Rzecz o profetyzmie Mickiewicza, Warszawa 1988, s. 195). O związkach znaczenia liczby czterdzieści i cztery z koncepcjami Saint-Martina pisali także Czesław Latawiec oraz Marek Nowak (Cz. Latawiec, Dziady Adama Mickiewicza: nowe naświetlenie problemów, Poznań 1929; M. Nowak, „Czterdzieści i cztery”. Tropem nieznanego filozofa, w: Mickiewicz mistyczny, pod red. A. Fabianowskiego, E. Hoffmann-Piotrowskiej, Warszawa 2005, s. 112-121). Zdzisław Kępiński wskazywał na szereg nurtów ezoterycznych, którymi mógł się Mickiewicz inspirować, nadając wyzwolicielowi imię czterdzieści i cztery: böhmizm, kabała, koncepcje Henricusa Corneliusa Agrippy von Nettesheima, pitagoreizm, rosyjski saint-martinizm i alchemia. Badacz poprzez wykorzystanie zasad gematrii w liczbie czterdzieści i cztery rozszyfrował 
liusz Kleiner, Stanisław Kolbuszewski, Zdzisław Kępiński, Wiktor Weintraub) upatrywali nowego Adama, a interpretowali ją w kontekście Kabały bądź pism Saint-Martina. Należy jednak zaznaczyć, że dla Böhmego i kontynuatorów jego myśli (w tym wspomnianego Saint-Martina) nowym Adamem był Chrystus, zaś restytucja kondycji człowieka w Adamie oznacza chrystianizację ludzkości ${ }^{47}$. Kolbuszewski wskazał na liczne nawiązania w Widzeniu Księdza Piotra do pism Saint-Martina i podkreślał, że nowy zbawca według wyżej wymienionego neognostyka i Mickiewicza, to Chrystus ${ }^{48}$. Natomiast Weintraub dowodził, że liczba cztery w scenie V symbolizuje jednostkę spełniającą funkcję pośrednika pomiędzy Bogiem a człowiekiem, której czyny przekroczą dokonania Chrystusa ${ }^{49}$. We wspólnotach teozoficznych, które inspirowały się myślą Böhmego oraz jej kontynuatorów, uważano, że biblijny Adam symbolizował ludzkość w jej trzech aspektach: ducha, duszy i ciała ${ }^{50}$. W Starym Testamencie człowiek został przedstawiony jako A.D.M. (czyli Adam), co oznacza:

A - Aleph: liczba 1, stawanie się, objawienie, źródło, z którego wywodzi się wszystko: Duch.

D - Daleth: liczba 4, znaczy „wyrównujący” albo „drzwi”; znamienne określenie dla działalności duszy.

M - Mem: liczba 40, tzn. ten, który kończy, który spełnia, który wykonuje: postać cielesna. $^{51}$

A zatem liczba cztery oznaczała działania duszy i, jak wskazywał Weintraub, rodzaj pośrednictwa. Liczba czterdzieści doczekała się w badaniach nad sceną V znacznie bogatszej egzegezy. Leonard Górnicki w studium na temat wpływu böhmizmu na nowoczesną gnozę przytacza szereg sposobów rozumienia liczby czterdzieści, fundamentalnej dla organizacji wspólnot pragnących praktykować życie podług wskazań Böhmego:

Liczbę 40 traktowano jako świętą. Zgodnie z przyjętą numerologią 1 była odpowiednikiem jedności, 2 - powtórzoną jednością, a 4 - harmonią. Szczególnej roli liczby 40

pojęcie „Lud”, „Duch”, „Baran” (jako znak astralny Chrystusa), „Lud Ludów”, „Zbawienie Narodów”, „Ludów Odkupienie”, „Narodu Odkupienia”, a także „Polska i Litwa” (Z. Kępiński, Widzenie Ks. Piotra jako hierofania narodu, w: tegoż, Mickiewicz hermetyczny, Warszawa 1980, s. 262-292).

47 M. Bierdiajew, Sens twórczości. Próba usprawiedliwienia człowieka, przeł. H. Paprocki, Kęty 2001, s. 124-129.

48 S. Kolbuszewski, Ziemski Mesjasz Narodów. O,Widzeniu Ks. Piotra”, Poznań 1930, s. 40.

49 W. Weintraub, dz. cyt., s. 157 i 193-195.

50 J. van Rijckenborgh, Elementarna filozofia nowoczesnego Różokrzyża, Wrocław 1999, s. 88 .

51 Tamże, s. 88 . 
dowodzić miała Biblia. Bóg nakazał deszczowi padać 40 dni i 40 nocy podczas potopu biblijnego Mojżesz spędził 40 dni i nocy z Bogiem na Górze Synaj. Dzieci Izraela wędrowały przez pustynię z Mojżeszem przez 40 lat. Saul i Dawid, każdy z osobna, rządzili Izraelem przez 4o lat. Czterdzieści łokci miała świątynia przed sanktuarium, tj. Miejscem Najświętszym (1 Ks. Królewska 6:17). Jezus pościł 40 dni i 40 nocy na pustyni (Mateusz 4:2). Po swym Ukrzyżowaniu Jezus Chrystus przez 40 dni ukazywał się apostołom (Dzieje Apostolskie 1:3). W życiu codziennym wspólnoty Kelpiusa liczba 40 odgrywała istotną rolę. Jej członkowie mieszkali razem w samotni, która mierzyła 40 na 40 stóp, z kątami ukierunkowanym ku czterem stronom świata. Cmentarz wspólnoty w Germantown miał wymiary 40 na 40; [...] Dodam, że w ezoteryce liczba ta ma istotne znaczenie..$^{52}$

Część przywołanych znaczeń liczby czterdzieści odnotowali w swoich interpretacjach Kolbuszewski i Weintraub ${ }^{53}$. Warto rozważania badaczy uzupełnić o rozumienie tej liczby przez Böhmego:

A więc kiedy nadszedł czas, aby z Raju zstąpił ponownie prawdziwy bohater i stał się dzieckiem dziewicy, doszło również do walki pomiędzy trzema zasadami. Wówczas bohater ów został ponownie postawiony przed drzewem pokuszenia, gdzie musiał pomyślnie zdać trudny egzamin oraz wytrzymać próbę trzech zasad, co nie udało się pierwszemu Adamowi. Jego walka trwała czterdzieści dni i czterdzieści nocy - tak długo jak walka Adama w raju i ani godziny dłużej. I tak oto bohater dokonał przezwyciężenia. ${ }^{54}$

Liczba czterdzieści w Biblii i pismach neognostyków oznaczała zatem okres próby dla wspólnoty i jednostki, z której wychodziły one zwycięsko. W scenie $\mathrm{V}$ odkupiciel jest opisywany zarówno jako jednostka, jak i zbiorowość. Trzeba więc rozważyć hipotezę, której na podstawie dostępnych faktów i źródeł nie da się w sposób bezdyskusyjny dowieść, że liczby czterdzieści i cztery oznaczają wspólnotę, która po czasie próby, podobnej do doświadczeń Jezusa, poprzez pełnienie posłannictwa Chrystusowego, przyczyni się do odzyskania przez narody wolności oraz odrodzenia chrześcijańskiego. Liczba czterdzieści może oznaczać także postać cielesną wskrzesiciela narodu, przez co najprawdopodobniej zostało podkreślone, że odkupiciel przyjmie postać konkretnego człowieka czy też konkretnej zbiorowości. Natomiast liczba cztery przypuszczalnie wskazuje na udział duszy w jego ukonstytuowaniu się - duszy związanej, według Böhmego i kontynuatorów jego myśli, z wolą, której ukierunkowanie ku Bogu bądź szatanowi, przyczynia się do urzeczy-

52 L. Górnicki, O wplywie myśli Jacoba Böhmego (1575-1624) na nowoczesna gnozę, w: Wpływy myśli hermetycznej Jakoba Böhmego na życie i twórczość Adama Mickiewicza oraz jej współczesna recepcja, pod red. L. Górnickiego, Katowice 2011, s. 149-150.

53 S. Kolbuszewski, dz. cyt., s. 35. W. Weintraub, dz. cyt., s. 193-195.

54 J. Böhme, Żyjąc w prostocie Chrystusa, s. 107; podkr. - K.F. 
wistniania się w historii boskości lub zła. Więzień w Prologu wskazuje, że dusza jest obszarem tajemniczym dla człowieka i wartym jego badań, natomiast Ksiądz Piotr w scenie V zauważa rozwój wskrzesiciela „duszą i ciałem” (190). Mickiewicz w Księgach pielgrzymstwa polskiego podkreślał, że naród polski nie jest Chrystusem, zaś jego duszą jest pielgrzymowanie, którego przebieg przypomina doświadczenia Syna Bożego:

Duszą Narodu polskiego jest pielgrzymstwo polskie. [...]

Ale Naród polski nie jest bóstwem jak Chrystus, więc dusza jego pielgrzymując po otchłani zbłądzić może, i byłby odwleczony powrót jej do ciała i zmartwychwstanie..$^{55}$

Można zatem przypuszczać, iż liczba cztery w Widzeniu Księdza Piotra wskazuje na element duszy, czyli najprawdopodobniej także na ukierunkowanie woli ku Bogu, imitatio Christi, a zatem Chrystusowy (czyli jednocześnie osobowy) charakter wspólnoty realizującej boskie posłannictwo wolności wśród narodów europejskich. Dopart dowodził, że w dramacie misja zbawcza Polaków w postaci ukonstytuowania męża opatrznościowego wywodzi się od Boga i obejmuje Łaskę, a następnie „odpowiedź człowieka na inicjatywę Odkupiciela, odpowiedź wyrażającą się metanoją i zasługą chrześcijańską (które płyną z naśladowania Chrystusa), a nie jakąś gnozą polityczną, rewolucją czy idealną praktyką ustrojowo-polityczną ${ }^{56}$. Ideę imitatio Christi w Dziadach drezdeńskich można uznać za generator czynu o znaczeniu politycznym i metafizycznym, skuteczną metodą działania w historii, o czym wspominał zagadkowy Duch w Prologu. Wyłonienie namiestnika wolności z prześladowania społeczeństwa polskiego wymagałoby w takim razie transformacji duchowej narodu. O konieczności odnowy o charakterze religijnym emigracji i jej roli wśród nacji europejskich pisał Mickiewicz już w 1832 roku w liście do Joachima Lelewela ${ }^{57}$.

W III części Dziadów doświadczenie opresji politycznej może spowodować dwie skrajne postawy. W upadku Konrada zostało najprawdopodobniej ukazane samodzielne ukierunkowanie woli ku złu, a przez to partycypacja w siłach szatańskich w walce z Bogiem. W kreacji Więźnia można odnaleźć elementy buntu Lucyfera i biblijnego Adama w ujęciu Böhmego. Natomiast w widzeniu Księdza Piotra zostało ukazane doświadczenie oraz przezwyciężenie męczeństwa wynikającego z sytuacji polityczno-historycznej poprzez

A. Mickiewicz, Księgi pielgrzymstwa polskiego, w: tegoż, Dzieła..., t. 5: Proza artystyczna i pisma krytyczne, oprac. Z. Dokurno, Warszawa 1999, s. 21.

56 B. Dopart, dz. cyt., s. 198.

57 List do Joachima Lelewela, Drezno, 23 marca 1832, w: A. Mickiewicz, Dzieła..., t. 15, s. 139. 
ukierunkowanie woli ku Bogu, uwewnętrznienie doświadczeń Syna Bożego oraz praktykowanie imitatio Christi, co umożliwi odzyskanie przez narody wolności. Bunt Konrada nie prowadzi do realnego działania w historii na rzecz wolności i równości. Dopart wskazywał, że symbolika i fabuła adamicka stanowi spoiwo Dziadów drezdeńskich ${ }^{58}$. W dziele można odnaleźć schemat upadku Adama (w kreacji Konrada) i jego restytucji (w wizerunku odkupiciela narodów). Władzą ludzką decydującą o partycypacji w siłach antyboskich i boskich jest wola, co zostało wyeksponowane przez Ducha w Prologu. Moc woli prowadzącej do czynu historycznego leży zatem nie w tytanicznym czy też prometejskim buncie Konrada, w jego dążeniu do sprawowania zsekularyzowanej władzy (co postulowali Thomas Hobbes i Fryderyk II, osoby wymienione w scenie III jako reprezentanci szatana), ale w naśladowaniu Chrystusa. Mickiewicz w III części Dziadów wskazał na usankcjonowanie mistyczne polityki, a tym samym na znaczenie jednostkowej i zbiorowej kondycji duchowej dla historii narodów. Toteż w III części Dziadów, jak wskazywał Kolbuszewski, można odnaleźć romantyczne oczekiwanie przemiany, które spowodowało zaangażowanie autora Pana Tadeusza w Domek Jańskiego, Koło Sprawy Bożej i wreszcie w Legion Rzymski.

\section{NEOGNOSTYCZNE WIZJE WOLI I NAŚLADOWANIA CHRYSTUSA}

\section{A III CZĘŚĆ DZIADÓW}

Zagadkowego Ducha, którego wypowiedź kończy Prolog, można uznać za istotę obwieszczającą uniwersalną prawdę o mocy ludzkiej woli i nieświadomości wspólnot ludzkich, o sile historiotwórczej, jaką dysponują. Mickiewicz w Księgach narodu polskiego podkreślał istnienie ścisłego związku pomiędzy wiarą, wolnością oraz wolą: „Na początku była wiara w jednego Boga, i była Wolność na świecie. I nie było praw, tylko wola Boga, i nie było panów i niewolników, tylko patriarchowie i dzieci ich"59. W słowach Ducha słyszymy echo słów Boehmego, że poprzez ukierunkowanie istniejącej przed jakimkolwiek bytem woli ku Bogu bądź szatanowi, człowiek partycypuje w siłach dobra lub zła w ich odwiecznej walce. W postawie Konrada, w jego pragnieniu widzenia profetycznego, stwórczo-zbawczej aktywności, dążeniu do przerwania milczenia Stwórcy oraz przejęcia władzy nad światem, można zauważyć elementy ukierunkowania woli ku złu w ujęciu Böhmego. Bohater uważa, że jego i świata istnienie jest oddzielone od Boga-stwórcy, nie zaś wpisane w historyczny moment rozwoju absolutu (Boga jako aktualizującej się potencji), którego pełnia nastąpi

59 A. Mickiewicz, Księgi narodu polskiego, w: tegoż, Dzieła..., t. 5, s. 9. 
wraz z nadejściem Królestwa Bożego. Konrad, pojmując siebie jako partykularny byt, ustanawiał własną tożsamość i obszar egzystowania, co zdaniem Böhmego, stanowiło podstawę grzechu Lucyfera oraz biblijnego Adama. Mickiewicz w kreacji Więźnia zawarł najpewniej krytykę nowożytnego ujęcia idei imitatio Dei, romantycznego absolutyzowania jednostki, solipsyzmu i elementów nihilistycznych w niemieckich systemach idealistycznych. Poeta, rzecz jasna, nie tyle polemizował $\mathrm{z}$ ideami filozoficznymi, co przedstawił ich oddziaływanie na kondycję i świadomość jednostek na początku XIX wieku oraz wskazał na ich destrukcyjny potencjał.

Natomiast w widzeniu Księdza Piotra można zauważyć podobieństwa między wizją prześladowania narodu polskiego i wyłonienia się odkupiciela a Böhmowskim ujęciem ukierunkowania ku Bogu poprzez imitatio Christi oraz interioryzację doświadczeń Chrystusa. Według neognostyka ze Zgorzelca człowiek poprzez naśladowanie Chrystusa partycypuje po stronie dobra $\mathrm{w}$ walce ze złem i realnie wpływa na losy absolutu. Praktykowanie imitatio Christi najprawdopodobniej dla Konrada będzie oznaczać akceptację Boga jako dawcy życia oraz obranie Chrystusa za wewnętrzną zasadę postępowania. „Wskrzesiciel narodów” w wizji Księdza Piotra posiada doświadczenia podobne do Jezusa, ewoluuje do bogoczłowieczeństwa oraz wprowadza wolność wśród nacji. Nacisk, jaki położył Mickiewicz na podobieństwo pomiędzy odkupicielem a Chrystusem bez jednoznacznego utożsamienia go z Synem Bożym, pozwala przypuszczać, że narodowi polskiemu w Mickiewiczowskim arcydramacie zostało przypisane pełnienie szczególnego posłannictwa Chrystusowego. Prześladowania porozbiorowe predestynują naród polski spośród innych nacji do owej misji, ale, by ją wypełnić, najprawdopodobniej konieczna jest transformacji duchowa. Zdaniem autora Aurory, człowiek realizuje posłannictwo Chrystusowe poprzez imitatio Christi.

W kreacji Księdza Piotra odnajduje elementy naśladowcy Syna Bożego w ujęciu Tomasza à Kempis. Wyobrażenie mocy woli ludzkiej i znaczenia naśladowania Chrystusa dla losów jednostki i dziejów Mickiewicz mógł zaczerpnąć z pism neognostyka ze Zgorzelca, kontynuatorów lub popularyzatorów jego myśli. Saint-Martin po zetknięciu się z böhmizmem zrewidował swoje wcześniejsze poglądy i zaczął tłumaczyć na język francuski dzieła siedemnastowiecznego mistyka. Rafał Marceli Blüth dowodził, że rosyjscy saint-martiniści studiowali przede wszystkim idee Böhmego i to nimi zainteresował się Mickiewicz, czego ślady odnajdujemy w wizji upadku Konrada ${ }^{60}$. Inteligencja rosyjska w latach dwudziestych uważała siebie na odmianę mnichów pełnią-

R.M. Blüth, dz. cyt., s. 134 i n. 
cych funkcję nauczycielską i religijną ${ }^{61}$. Toteż spekulacje niemieckiego teozofa na temat znaczenia imitatio Christi mogły być bardzo atrakcyjne dla elit intelektualnych w Rosji. Jak wskazuje Piórczyński, neognostyczne wykładnie Böhmego były znane $\mathrm{w}$ dobie romantyzmu, nawiązania i inspiracje płynące z dzieł mistyka ze Zgorzelca odnajdujemy u wielu twórców z początku XIX wieku $^{62}$. W Dziadach drezdeńskich można zauważyć unarodowienie oraz upolitycznienie Böhmowskiej wizji woli i naśladowania Chrystusa. Mikołaj Bierdiajew dowodził, że niemiecka metafizyka zracjonalizowała neognozę Böhmego i jego poprzedników (Mistrza Eckharta, Taulera, Suzo) i na jej podstawie sformułowała filozofię podmiotu ${ }^{63}$. Można przypuszczać, że Mickiewicz, inspirując się myślą Böhmego, twórczo przekształcając wykładnie böhmistyczne czy też kreśląc antropologiczne wyobrażenia korespondujące $\mathrm{z}$ wizjami autora Aurory, przedstawił w Dziadach drezdeńskich problem romantycznych sporów o podmiot. Wizja człowieka zawarta w dramacie jest woluntarystyczna, gdyż nie rozum, nie czucie, którego siłę afirmuje Konrad, ale wola decyduje o ukonstytuowaniu się podmiotowości i jej metafizycznej (a także historycznej) jakości oraz mocy. Mickiewiczowską koncepcję jednostki można wpisać w nurt rechrystianizacji w duchu nowożytnej neognozy oświeceniowych i romantycznych wizji człowieka.

Problem antropologiczny w III części Dziadów można uznać za ściśle związany z kwestią ukonstytuowania się wspólnoty zdolnej do działania w historii, realizującej Chrystusowe posłannictwo. Bierdiajew za główny problem böhmizmu i jego kontynuacji uznał wykrystalizowanie się „świadomości wspólnotowej" " . Osobą najbardziej świadomą w dramacie jest Ksiądz Piotr, praktykujący imitatio Christi i dostępujący epifanii losu narodu oraz jego eschatologicznego znaczenia. Natomiast Senator, związany silnie z siłami szatańskimi, jest całkowicie nieświadomy źródeł przyznanej mu władzy i roli własnych działań w historii. Nie wie, że poprzez czynienie zła tworzy czasoprzestrzeń dla ukonstytuowania się dobra, wyłonienia się odkupiciela z prześladowania narodu polskiego. Aby wykrystalizował się namiestnik wolności w społeczeństwie, konieczne jest uzyskanie świadomości na temat eschatologicznej roli

61 B. Uspienski, Inteligencja rosyjska jako fenomen kultury rosyjskiej, w tegoż, Religia i semiotyka, wyb., tłum. i przedm. B. Żyłko, s. 105.

62 J. Piórczyński, Absolut, człowiek, świat..., s. 29-30.

63 M. Bierdiajew, Zarys metafizyki eschatologicznej. Twórczość i uprzedmiotowienie, przeł. W. i R. Paradowscy, Kęty 2004, s. 28-29. Podobnie uważają: Kołakowski, Piórczyński i Augustyniak, dodając Teologię niemiecką jako fundamentalne dzieło dla niemieckiej metafizyki (zob.: L. Kołakowski, dz. cyt., s. 159-175; J. Piórczyński, Absolut, człowiek, świat... , dz. cyt., s. 304-319; P. Augustyniak, dz. cyt., s. 246-258).

64 M. Bierdiajew, Filozofia wolności, przeł. E. Matuszczyk, Białystok 1995, s. 52-53. 
postaw poszczególnych obywateli oraz duchowe odrodzenie. Ryszard Przybylski twierdził, że polski mesjanizm stanowił formę sekularyzacji nowotestamentowego odrodzenia, o czym świadczy Widzenie Księdza Piotra, bluźnierczy fragment dramatu ${ }^{65}$. Jednakże w scenie $V$ została przedstawiona przede wszystkim wizja rechrystianizacji historii i społeczeństwa oraz wyłanianie się nowej elity narodu polskiego z praktyki naśladowania Chrystusa. Ksiądz Piotr dowodzi Senatorowi, że: „Bóg czasem daje władzę w ręce złego ducha” (229). Cyryl Adamski w wzięciu na siebie przed Bogiem grzechów Konrada przez bernardyna upatrywał odejście przez Mickiewicza od dogmatów kościelnych ${ }^{66}$. W III części Dziadów zostało zaakcentowane, że bohater pojedna się z Bogiem i wspólnotą narodową. W Widzeniu Księdza Piotra prześladowanie Polaków nie tylko zostało ujęte jako ukrzyżowanie, ale także wskazano na bezpośredni jego związek z ideą wolności - „A matka Wolność u nóg zapłakana stoi” (189). Mickiewicz, wskazując na ścisłe powiązanie pomiędzy chrystianizmem a wolnością narodów, mógł nawiązywać do idei Lammenais’ego, potępionych przez Grzegorza XVI w encyklice Mirari vos z 1832 roku. Postawa i światopogląd Księdza Piotra, w którym odnajdujemy elementy imitatio Christi, była sprzeczna z ówczesną polityką papiestwa, chociażby dlatego, że bernardyn podważał utożsamianie każdego monarchy i władzy królewskiej z namiestnictwem Boga na ziemi, wyrażone expressis verbis w Mirari vos ${ }^{67}$.

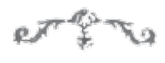

A B S T R A C T

\title{
Jakub Böhme's Neognosis and Adam Mickiewicz's
}

Forefathers' Eve. Part III.

\author{
Will, Human Fall and Christ's Imitation
}

The article presents a problem of will included in III part of Forefathers' Eve (Dziady. Część III). The Ghost in Prolog indicated that man, through his will, can successfully affect history and participate in eternal fight between good and evil. This perception of will corresponds with Jakub Böhme's neognostic interpretation. In the theosoper's opinion, the man can direct his will to either good or evil, and not only his salvation depends on it but also the world's history. According to Böhme, the will

65 R. Przybylski, Nadprzyrodzony sens poczynań narodów, w: tegoż, Słowo i milczenie bohatera Polaków, s. 189-19o.

66 C. Adamski, Romantyzm i filozofia w „Dziadach”, Kraków 189o, s. 12. Także Dalman wskazywała, że w scenie V dramatu została przedstawiona idea naśladowania Chrystusa oraz przypisanie narodowi polskiemu roli analogicznej do roli Kościoła (M. Dalman, dz. cyt., s. 239).

67 Grzegorz XVI, O liberalizmie, przeł. F. Rastafiński, Warszawa 2003, s. 19. 
directed towards God involves imitating Christ, interiorizing his experience, which all leads directly to unia mystica. In Konrad's fall it is possible to find many parallels to Böhme's imagination about will directed towards evil. But in Vision (Widzenie) of Priest Piotr, Mickiewicz showed the transformation of the Polish nation to fulfill Christ's mission among other nations, possibly because of the experience of oppression and practicing imitatio Christi.

\section{K E Y W O R D S}

Adama Mickiewicz, Jakub Böhme, neognosis, Forefathers' Eve. Part III (Dziady. Część III), will, imitatio Christi 